\title{
Process Innovation and Competitive Advantage in Telecommunication Companies
}

\author{
Peter Chege Mugo, United States International University-Africa, Kenya \\ Juliana Mulaa Namada, United States International University-Africa, Kenya
}

\begin{abstract}
Innovation is key to achieving a competitive advantage. In a bid to achieve competitive advantage, companies have considered different types of innovation. Each firm establishes its own competitive niche depending on the conditions that allow it to be productive within that specific niche. Process innovations have emerged as some of the key competitive fronts for many firms including the telecommunications industry. This paper focuses on establishing the effect of process innovation on the competitive advantage of the telecommunication industry in Kenya. The study adopted a descriptive research design using a sample size of 26 active telecommunications companies in Kenya. The respondents were mid and top-level managers. The linear regression model showed process innovation statistically affects the competitive advantage of telecommunication companies in Kenya $(\beta=.302 \mathrm{t}$ $=4.952$, p\&lt;.05). The study recommends telecommunication companies to design processes that provide optimum returns and use disruptive technology to design innovative processes.
\end{abstract}

\section{KEYWORDS}

Communication Authority of Kenya, Competitive Advantage, Disruptive Innovation, Kenya, Market Maturity, Mobile Phone, Process Advancement, Process Innovation, Telecommunication Industry

\section{INTRODUCTION}

Competitive advantage of any kind requires the harmonization of resources for the sustainability of any process innovations. From a theoretical perspective, assets are the resource endowments the business has accumulated, and capabilities are the glue that keeps these assets together and enables them to be deployed advantageously (Arifiani, 2019). Both assets and capabilities allow firms to make the best strategic choices for perfect competition and how to add value in customer value chain, development of new production and expansion in new markets (Nawal \& Cherif, 2019). However, it should be noted that not all assets and capabilities appear strategic and thus sources of competitive advantage. Any such competitive advantage occurs only when there is a situation of resource heterogeneity and resource immobility that harmonizes the innovative process of the firm to achieve a competitive edge over its rivals (Blotch \& Metclef, 2018). 
Process innovation involves the usage of another or altogether upgraded creation or conveyance technique. This requires huge changes in strategies, gear or potentially programming through process development and process advancement. Process development offers the roads for securing and enhancing the quality and to spare expenses. It empowers the organization of the organizations' activities raising adequacy and productivity (Moyano-Fuentes, Maqueira-Marín \& Bruque-Cámara, 2018). Process development is intended to diminish unit expenses of conveyance and generation, convey new or create new fundamentally enhanced items and increment quality (Atalay, Anafarta \& Sarvan, 2013). Bashir and Verma (2017), concurred that process development is an essentially enhanced conveyance strategy or selection of another generation procedure. In telecommunication industry, Igami (2017) indicated that process development offers the roads for securing and enhancing the quality and sparing expenses through expansion of GSM networks.

\section{Research Problem}

Moyano-Fuentes et al., (2018) note that companies in Western Europe have continuously fought wars on the process innovation front leading to profit-making as well as heavy losses in case of those firms that cannot sustain innovative processes on specific markets. In Africa, studies have shown there is a heavy reliance on foreign companies in surviving market competition but this can only be sustained if the process innovations are well designed to accommodate new market changes (Song, 2019). The competitiveness of such firms relies on their ability to enhance processes that will be appealing to the market even though this could involve lots of costs that must be borne by the telecommunication companies. Without managing the costs, a firm will fail to be competitive especially in the busy telecommunications market.

Kenyan telecommunications industry has been very competitive (Madsen \& Leiblein, 2015) due to its previous low penetrration rates in mobile and fixed markets (CAK, 2015). The first players were Safaricom and Kencell, but the entrance of other network operators brought competition in the industry. Telkom Kenya and Yu Mobile acquired mobile licenses in 2008 but in 2014, Yu Mobile was bought off by two leading mobile companies. The increasing competitive situation led to price conflicts, which led to lowest prices in Africa (Osano \& Koine, 2016).

The increase in competition drives telecommunication companies to employ various innovative and competitive strategies in order to survive in the industry (David, 2019). This boils down to how competitive firms innovative process is going to be to remain ahead of the competition (Ole Kulet et al.,, 2019). Despite the competition, the affluent financial requirements mark the entry onto the telecommunications market difficult yet lucrative to join since a fall from such a market is costly (Njoh, 2018). This leads to the big question that informed this study: does process innovation influence the competitive advantage of telecommunication industry? The context of previous studies were different from the current study hence a gap to be filled through this empirical study; to establish the influence of process innovation on the competitive advantage of telecommunication industry in Kenya.

\section{LITERATURE REVIEW}

\section{Theoretical Underpinning of Process Innovation and Competitive Advantage}

Disruptive innovation theory by Christensen, McDonald, Altman and Palmer (2018) has been used to describe innovation driven-growth. The scholars define disruptive innovation as a procedure through which a product or service flourishes at the bottom level of a relatively mature market and then persistently moves up the market levels dislodging established competitors in the process. According to Vecchiato (2017), this means that a whole new market together with a value network is created that ends up disrupting an existing market and value network along with established leading firms and alliances. 
Accordingly, disruptive innovation theory asserts that disruptive innovations are produced by entrepreneurs and outsiders who are not part of existing market-leading companies (Christensen et al., 2018). This is points out that the risk associated with investing in a disruptive innovation is higher than other evolutionary forms of innovation and that the whole process of development takes longer (Corsi \& Di Minin, 2014). Disruptive innovation theory identifies some characteristics of a disruptive business environment. First, established businesses are often associated with lower unsophisticated margins and smaller target bazaars (Reinhardt \& Gurtner, 2018). Additionally, their products and services appear simple compared to the disruptive innovators so much so that they may not appear as attractive as existing solutions. These lower levels of the market compromise lower gross limitations thus they are unattractive to consumers.

Disruptive advancement idea has found wherein the centrality chain benefits will live in the prospect as ventures change and develop (Christensen et al., 2018). A key instinct is that when merchandises are not attractive to the necessity execution of customers, firms depend on extremely internal items designs that are associated and coordinated to abuse item execution (Li, Porter \& Suominen, 2018). As an innovative industry emerges, performance-driven antagonism may be wild with the end goal that organizations can't bear to expect measured designs because of the standard to seclusion tends to bargain execution (Gobble, 2016). This study specifically chose the disruptive theory as it resonates with process innovations that have defined the market in the telecommunication industry. An innovative process is a form of disruptive innovation that is very easy to be identified with customers of a given firm.

\section{Process Innovation and Competitive Advantage}

Innovative processes occur when organizations purpose acquiring a yield they are engaged with changing over information, for example, labor and raw material (administrations or items). This process is defined as a connection of a set of activities tailored to convert input into output which is offered to the consumer (Vogelsang, 2017). It is also fair to characterize process advancement as an improvement driven by inside creation destinations. Likewise, process advancement alludes to enhance the adequacy and productivity of the manner in which the firm works (Haneda \& Ito, 2018). To quickly get into the competitive front, there is always a need for partnership with a well-established partner to help have synergies shared or symbiotic relationship. The competitive edge is even more defined when the partnering firm is unknown (May \& Schedelik, 2019).

Process innovation also alludes to uniting strategically creation strategies and critical changes in supporting exercises, for example, figuring, bookkeeping, acquiring and upkeep (Kim, Baek \& Lee, 2018). The association can grow new procedures independent from anyone else or with the help of the partnering or mother firms (David, 2017). Organizations embrace new procedures to contend with different associations and furthermore plan to fulfill their buyers who appreciate the use of new equipment software and hardware. Past contextual investigations have demonstrated that mechanization in the generation techniques has expanded the profitability and effectiveness of the firm (Landoni, 2017). This has always called for the new networks of the firm to be installed for a clear competitive advantage to be achieved. The jump from $2 \mathrm{G}$ to $3 \mathrm{G}$ and $4 \mathrm{G}$ networks is a good example of how competitive advantage was achieved by the firms that went into the new GSM improvements. To a large extent, the cost of GSM network switching pushed the competitive advantage to a newer level. Process advancement adds to changes in specific perspectives for example, conveyance procedures, innovations, gear's and which can likewise prompt a cost decrease (Lepoutre \& Oguntoye, 2018).

The degree to which a firm chooses to receive a procedure development is impacted by the extent of the firm. Process development venture shares are altogether identified with association measure. Fonseca (2014) contends that the structure and exercises of the R and D are affected by the association estimate and thusly impacts the development procedures. Extensive associations have more motivation to embrace process development as it expands cost productivity. Besides, huge associations have a more differentiated arrangement of capacities and abilities and have an expansive scope of items. 
Consequently, the presentation of process advancement diminishes cost-effectiveness along the different lines of creation (Aghion et al., 2019). Process development is intended to diminish unit expenses of conveyance and generation, convey new or to create a new fundamentally enhanced item and increment quality (Anning-Dorson, 2018).

Process advancement is the reception of essentially enhanced or new conveyance or creation technique. Organizational growth is emphatically related to process advancement (Hassan, Shaukat, Nawaz \& Naz, 2013). The scholars consider among SMEs in Finland attested that procedure advancement directly affected firm execution. Arnning-Dorson (2018) avowed a noteworthy and constructive outcome on organizations' execution from process development. Landoni (2017) uncovered that procedure development affects client results and advancement results. Process advancement was uncovered to be emphatically related to institution development (Ghezzi, Cortimiglia \& Frank, 2015). Reliable with this finding was David (2019) who additionally found a noteworthy relationship between innovation and association execution. Reports also indicate that SMEs concurred that association is decidedly related to process advancement (Desta, 2018).

Similarly, an examination that uncovered that procedure advancement is an imperative element in both market and monetary execution (Bryman \& Bell, 2015). This view holds a restricting perspective, announcing that absence of a talented workforce, absence of funds, lacking innovative work are for the most part obstructing process development in the SME segment (Caver, 2018). This has always been seen to be a region of competitive advantage that most firms tend to ignore but one that is easy to ascertain. Competitive advantage demonstrated through the salaries of new employees, retention of high numbers of both staff and customers as well as the ability to satisfy a large market coverage remains high in the competitive advantage index in the telecommunications market.

In Kenya, Mutua (2019) found that 75 percent of organizations uncovered a huge exertion in making speculations of present-day apparatuses of creation as a technique of process advancement even through the discoveries demonstrated that SMEs discovered this extremely troublesome and costly to adapt. The examination found that $56 \%$ concurred that procedure development added to cost decrease. This to a large extent has always played a negative role in the competitive advantage of firms especially the smaller players on the market. Efficiency and profitability for most of the firms on the telecommunications market, therefore, remain elusive. Specifically, firms like Safaricom and Airtel have continued to lead the market with more market share and expansion of their coverage through partnerships of installation of communication masts and the latest technology.

Another study on examination on the connection between advancement systems and upper hand in the United Bank of Africa Limited in Kenya by Kingiri and Fu (2020) uncovered that UBA intended to serve the Kenyan money related part by showcase division. The UBA could offer tweaked monetary administrations to offer for the diverse market fragments. This played a great part in the business competitive advantage of UBA as it witnessed increased market share and large coverage. This competitive nature of UBA has thus retained its market competitive advantage on the Kenyan market. Aghion et al. (2019) found a noteworthy connection between the measure of the association and process advancements for authoritative execution. Song (2019) inquired about concentrated because of advancement techniques on the execution of firms in the telecoms division in Kenya and discovered confirmation that procedure development directly affected association functionality.

\section{Conceptual Framework}

Conceptual framework is defined as the analytical tool that diagrammatically relates the study variables capturing real and practical reminders that can be applied (Creswell \& Poth, 2018). In this study, the researcher identified the constucts of the independent and dependent variable based on literature view and innovation theory. The dependent variable is competitive advantage and the independent variables process innovation with three constructs as presented in Figure 1. 
Figure 1. Conceptual framework (Researcher, 2020)

Independent Variables (Process Innovation)
Dependent Variable

\begin{tabular}{|l|l|}
\hline $\begin{array}{l}\text { Service Delivery Methods } \\
\text { - Production techniques } \\
\text { - Employee creativity }\end{array}$ & $\longrightarrow$\begin{tabular}{ll|}
\hline Cost Optimization \\
- Cost cutting \\
- Wastage reduction \\
- New workflow
\end{tabular} \\
\hline $\begin{array}{l}\text { New Organization Structure } \\
-\quad \text { Internal firm skills } \\
-\end{array}$ \\
\hline $\begin{array}{l}\text { - Communication flow } \\
\text { - Reorganizing firm structure }\end{array}$ \\
\hline
\end{tabular}

\section{Operationalization of the Research Variables}

To further test the hypothesis, the variables were operationalized with various dimensions and indicators as indicated in Table 1.

\section{RESEARCH METHODOLOGY}

This section covers the research design used, the population, sample selection, research procedure and data analysis methods.

\section{Research Design}

The descriptive research design was used. The descriptive study design is meant to explore a phenomenon on the ground without necessarily further interrogation (Creswell \& Poth, 2018). In this study, the influence of process innovation on competitive advantage was the phenomenon on study.

Table 1. Operationalization of variables and hypothesis testing

\begin{tabular}{|l|l|l|l|}
\hline \multicolumn{1}{|c|}{ Independent Variables } & \multicolumn{1}{|c|}{ Dimension } & \multicolumn{1}{c|}{ Indicator } & \multicolumn{1}{c|}{ Key Authors } \\
\hline Service Delivery (X1) & - Procedural & $\begin{array}{l}\text { Production techniques } \\
\text { Employee creativity }\end{array}$ & Aghion et al., (2019) \\
\hline Cost Optimization (X2) & - Cost leadership & $\begin{array}{l}\text { Cost cutting } \\
\text { Wastage reduction } \\
\text { Low pricing }\end{array}$ & Carve (2018) \\
\hline $\begin{array}{l}\text { Organization Structure } \\
\text { (X3) }\end{array}$ & - New Workflow & $\begin{array}{l}\text { Workflow restructuring } \\
\text { Communication flow } \\
\text { Reorganizing firm structure }\end{array}$ & Kim e12) \\
\hline Dependent Variable (Y) & & $\begin{array}{l}\text { Market coverage } \\
\text { Market share } \\
\text { Internal firm skills } \\
\text { Firm Resources }\end{array}$ & May \& Schedelik (2019) \\
\hline Competitive Advantage & -Firm assets and skills & \\
\hline
\end{tabular}

Source (Researcher, 2020) 


\section{Population and Sample Selection}

The target population comprised of all 26 telecommunication companies licenced by communiaciton authority as of 2018. Based on the market share, ten companies had a market share of more than $97.5 \%$, while the remaining had less than the $2.5 \%$ of telecommuncation market share. The unit of analysis were 26 telecommunication companies while the unit of observation were management employees of these telecommunication companies.

As of 2019, the total number of employees in telecommunication industry was 8,689 (CA, 2019; KNBS, 2020). The total number of managers in each company varied and the company with clear percentage of managers was Safaricom at $17.6 \%$ (Safaricom, 2019). With the variance, the researcher worked with $30 \%$ of the total population as presentation of managers. Sample size was calculated using the Cochran formula in two steps:

- $\quad$ e is the desired level of precision (5\% margin of error);

- $\mathrm{p}$ is the (estimated) proportion of managers to the population $=30 \%$

$\mathrm{q}$ is $1-\mathrm{p}$

$=(1.96)^{2}(0.3)(0.7) /(0.05)^{2}$

$=322.69$

To obtain higher confidence level, the sample size was modified by using this equation:

$$
n=\frac{n_{0}}{1+\frac{\left(n_{0}-1\right)}{N}}
$$

- $\quad \mathrm{n}_{0}$ is Cochran's sample size (322.69);

- $\quad \mathrm{N}$ is the population size of telecommunication industry $(8,689)$;

- $\mathrm{n}$ is the adjusted sample size:

$323 /(1+(322 / 8689))=311$

\section{DATA COLLECTION TOOLS}

A structured questionnaire was used to collect data from the managers. The questionnaire had demographic information, and three constructs presenting the process innovation; service delivery methods, cost optimization/new workflow and new organization structure.

\section{Pilot Study}

Pilot was conducted among 20 respondents. The reliability test had Cronbach Alpha of $>0.9$ indicating good reliability (Cooper \& Schindler, 2011). On Validity, content validy was attained by subject experts who evaluated the questionnaire and were satisfied with the content while construct validity was attained by Average Variance Extracted (AVE) test which had $>0.5$ threshold indicating the constructs account for at least fifty percent of the variance in the items.

\section{Data Analysis Framework}

Descriptive and inferential statistics tests were performed. Descriptive statistics test conducted were mean, standard deviation and skewness. The inferential statistics conducted were factor analysis, 
correlation analysis, and the regression analysis. The regression analysis model was used to test the research hypothesis.

$\mathbf{H}_{\mathbf{0}}$ : Process innovation has no significant effect on the competitive advantage of telecommunication companies in Kenya. The three sub-hypothesis as outlined on the conceptual framework:

$\mathbf{H}_{01 \mathbf{a}}$ : Service delivery has no significant influence on competitive advantage in the telecommunications industry of Kenya.

$\mathbf{H}_{01 \mathbf{b}}$ : Cost optimization has no significant influence on competitive advantage in the telecommunications industry of Kenya.

$\mathbf{H}_{\mathbf{0 1}}$ : Organization structure has no significant influence on competitive advantage in the telecommunications industry of Kenya.

\section{DATA ANALYSIS AND FINDINGS}

The results of the findings were presented in this section. First, demographic information of the respondents, the descriptive statistics, the factor analysis, the correlational analysis and lastly, the regression analysis.

\section{Demographic Information}

Through a simple random sampling, 247 managers were involved in the study presenting $79.4 \%$ which was adequate for analysis. The male respondents were (56\%) and the female respondents were (44\%). This shows a near balance (50\%) on gender of the management team in the telecommunication industry. Most managers at the telecommunication industry aged 24-35 years at 32\%, followed by those aged 36-45 years at 26\%, below 25 years at 15\%, 46-55 years at $10 \%$ and over 55 years were the least at $1 \%$. Cumulatively, more than half of the managers aged 25-45 years at 58\%. Uniquely, there was a high percentage (15\%) of managers below 25 years which is different in other industries.

\section{Descriptive Statistics}

As indicated on table 2, the mean (M), standard deviation (SD) and skewness (Skw) of each of the process innovation constructs: service delivery methods, cost optimization and new organization structure. The mean $(\mathrm{M})$ distribution of service delivery methods constructs was $(\mathrm{M}=3.85$, SD $=.510$ and Skw -.601). Similarly, the mean (M) distribution of the cost optimization constructs was $(\mathrm{M}=3.86, \mathrm{SD}=.693$ and $\mathrm{Skw}-.683)$ and lastly, the mean of the new organization structure constructs was $(\mathrm{M}=3.90, \mathrm{SD}=.614$ and $\mathrm{Skw}-.401)$.

In all the constructs, the mean was $4(\mathrm{M}=4$, zero decimal) which shows the managers 'agreed' on all the questions regarding service delivery methods, cost optimization/new workflow constructs and new organization structure constructs. Further, they all had lower SD $<1$ and negative skewness (Skw). This shows a high level of consensus among the respondents regarding the service delivery methods, cost optimization/new workflow constructs and new organization structure constructs.

Table 2. Mean and standard deviation of process innovation constructs

\begin{tabular}{|l|l|l|l|l|l|}
\hline & N & Mean & Std. Deviation & \multicolumn{1}{|c|}{ Skewness } & \multicolumn{1}{c|}{$\begin{array}{c}\text { Std. Error of } \\
\text { Skewness }\end{array}$} \\
\hline Service delivery methods & 247 & 3.8536 & .51032 & -.601 & .155 \\
\hline Cost optimization & 247 & 3.8583 & .69336 & -.683 & .155 \\
\hline New organization structure & 247 & 3.8995 & .61386 & -.401 & .155 \\
\hline
\end{tabular}

Source (Researcher, 2020) 


\section{Inferential Statistics}

In order to have further insights into the analytical approach to the study findings, it was necessary to carry out inferential statistics. This is necessary for real predicability of the population and in particular the determination of occurence of a phenomenon by chance or design. This study in particular heavily relied uon inferntial statistics since the nature of innovation plays a big role the basic design of destructive changes.

\section{Factor Analysis on Process Innovation}

Factor analysis was performed using the principal component analysis. The Kaiser-Meyer-Olkin of sampling adequacy was 0.6590 . The Bartlett's test of Sphericity was significant at $X^{2}(36, N=247)$ $=544.845, \mathrm{p}<.05$. This output shows the independent variable factors were adequate for extraction since Kaiser-Meyer-Olkin Measure was greater than 0.6 and the Bartlett's test was significant $(\mathrm{p}<.05)$ as indicated on table 3.

Three components were extracted with cumulative variance of $62.5 \%$. The extracted questions for the three components representing the process innovation; service delivery methods (PIS1, PIS2, PIS3), cost optimization/new workflow (PIC1, PIC2, PIC3) and new organization structure (PINO1, PINO2, PINO3) had factor loadings greater than 0.5. Further, the average of the components was calculated and the transformed data had a stronger component of 0.773 . This value was greater than the least factor loading value of .661. This shows the component loadings that informed the pattern matrix were stronger.

Table 3. Pattern Matrix on process innovation

\begin{tabular}{|c|c|c|c|c|}
\hline & \multicolumn{3}{|c|}{ Component } & \multirow[b]{2}{*}{ Kaiser-Meyer-Olkin } \\
\hline & $\begin{array}{l}\text { Service Delivery } \\
\text { Methods }\end{array}$ & $\begin{array}{l}\text { Cost Optimization/New } \\
\text { Workflow }\end{array}$ & $\begin{array}{l}\text { New Organization } \\
\text { Structure Features }\end{array}$ & \\
\hline PIS1 & .839 & & & \multirow{9}{*}{$\begin{array}{l}\mathrm{KMO}=0.6590 \\
\text { Bartlett's test } \\
\mathrm{X}^{2}(36, \mathrm{~N}=247)= \\
544.845, \mathrm{p}<.05\end{array}$} \\
\hline PIS2 & .875 & & & \\
\hline PIS3 & .661 & & & \\
\hline PIC1 & & .752 & & \\
\hline $\mathrm{PIC} 2$ & & .836 & & \\
\hline PIC3 & & .693 & & \\
\hline PINO1 & & & .729 & \\
\hline PINO2 & & & .906 & \\
\hline PINO3 & & & .665 & \\
\hline \multicolumn{4}{|c|}{$\begin{array}{l}\text { Extraction Method: Principal Component Analysis. } \\
\text { Rotation Method: Promax with Kaiser Normalization. }\end{array}$} & \\
\hline \multicolumn{4}{|c|}{ a. Rotation converged in 4 iterations. } & \\
\hline
\end{tabular}

Source (Researcher, 2020)

\section{Correlation Analysis}

As indicated in Table 4, there was significant correlation between the independent variable constructs and the dependent variable. Competitive advantage as dependent variable had a significant relationship with the following constructs representing the process innovation: service delivery methods $r$ (247) 
Table 4. Correlation analysis on process innovation and competitive advantage

\begin{tabular}{|c|c|c|c|c|c|}
\hline & & $\begin{array}{l}\text { Service } \\
\text { Delivery }\end{array}$ & $\begin{array}{c}\text { Cost } \\
\text { Optimization }\end{array}$ & $\begin{array}{l}\text { Organization } \\
\text { Structure }\end{array}$ & $\begin{array}{l}\text { Competitive } \\
\text { Advantage }\end{array}$ \\
\hline \multirow{2}{*}{$\begin{array}{l}\text { Service delivery } \\
\text { methods }\end{array}$} & Pearson Correlation & 1 & & & \\
\hline & Sig. (2-tailed) & & & & \\
\hline \multirow{2}{*}{$\begin{array}{l}\text { Cost optim/new } \\
\text { workflow }\end{array}$} & Pearson Correlation & $-.202 * *$ & 1 & & \\
\hline & Sig. (2-tailed) & .001 & & & \\
\hline \multirow{2}{*}{$\begin{array}{l}\text { Organization } \\
\text { structure }\end{array}$} & Pearson Correlation & .088 & -.088 & 1 & \\
\hline & Sig. (2-tailed) & .170 & .167 & & \\
\hline \multirow{2}{*}{$\begin{array}{l}\text { Competitive } \\
\text { advantage }\end{array}$} & Pearson Correlation & $.144^{*}$ & $.202 * *$ & $.133^{*}$ & 1 \\
\hline & Sig. (2-tailed) & .024 & .001 & .037 & \\
\hline \multicolumn{6}{|c|}{ *. Correlation is significant at the 0.05 level (2-tailed). } \\
\hline \multicolumn{6}{|c|}{ **. Correlation is significant at the 0.01 level (2-tailed). } \\
\hline
\end{tabular}

Source (Researcher, 2020)

$=.144, \mathrm{p}<.05$, with cost optimization/new workflow $(247)=.202, \mathrm{p}<.05$ and lastly with organization structure $\mathrm{r}(247)=.133, \mathrm{p}<.05$.

\section{Regression Analysis}

To determine the suitability of the data and the type of the regression analysis to be used, different regression assumptions were conducted. The result showed, data was normally distributed, there was linear relation between the process innovation and competitive advantage, the process innovation and competitive advantage variables were not multicollerated. From these findings, the linear regression model:

$Y=\beta_{0}+\beta_{i} x_{i}+\varepsilon$

$\mathrm{Y}=$ competitive advantage

$\beta_{0}=$ Constant

$\beta_{i}=$ process innovation/service delivery/cost optimization/organization structure/process innovation

$\varepsilon=$ Error term was selected to test the hypothesis of the study

$\mathbf{H}_{\mathbf{0}}$ : Process innovation has no significant effect on the competitive advantage of telecommunication companies in Kenya.

The three sub-hypothesis as outlined based on the three constructs of the study as outlined on the conceptual framework:

$\mathbf{H}_{\mathbf{0 1 a}}$ : Service delivery has no significant influence on competitive advantage.

$\mathbf{H}_{\mathbf{0 1 b}}$ : Cost optimization has no significant influence on competitive advantage.

$\mathbf{H}_{\mathbf{0 1 c}}$ : Organization structure has no significant influence on competitive advantage.

Table 5 shows the model summary of all the hypothesis. The output indicates that the unit influence of service delivery on the competitive advantage was $2.7 \%\left(\mathrm{R}^{2}=0.027, \mathrm{p}<.05\right)$, unit 
Table 5. Model summary of independent variable on competitive advantage

\begin{tabular}{|l|l|l|l|l|}
\hline & \multicolumn{1}{|c|}{ Service Delivery } & \multicolumn{1}{c|}{$\begin{array}{c}\text { Cost } \\
\text { Optimization }\end{array}$} & \multicolumn{1}{|c|}{$\begin{array}{c}\text { Organization } \\
\text { Structure }\end{array}$} & \multicolumn{1}{|c|}{$\begin{array}{c}\text { Process } \\
\text { Innovation }\end{array}$} \\
\hline R & $.164^{\mathrm{a}}$ & $.182^{\mathrm{b}}$ & $.156^{\mathrm{c}}$ & $.317^{\mathrm{d}}$ \\
\hline R Square & 0.027 & 0.033 & 0.024 & 0.100 \\
\hline Adjusted R Square & 0.023 & 0.029 & 0.02 & 0.089 \\
\hline Std. Error of the Estimate & 0.42215 & 0.42079 & 0.42265 & 0.40759 \\
\hline R Square Change & 0.027 & 0.033 & 0.024 & 0.100 \\
\hline F Change & 6.743 & 8.381 & 6.146 & 9.019 \\
\hline df1 & 1 & 1 & 1 & 3 \\
\hline df2 & 245 & 245 & 245 & 243 \\
\hline Sig. F Change & 0.01 & 0.004 & 0.014 & 0 \\
\hline
\end{tabular}

Source (Researcher, 2020)

influence of cost optimization on the competitive advantage was $3.3 \%\left(\mathrm{R}^{2}=0.033, \mathrm{p}<.05\right)$, and lastly, unit influence of organization structure on the competitive advantage was $2.4 \%\left(\mathrm{R}^{2}=0.024\right.$, $\mathrm{p}<.05$ ). On each model, the unit summary was less than $5 \%$.

The Linear regression of combined constructs to present the process innovation shows unit influence of process innovation on the competitive advantage was $9.1 \%\left(\mathrm{R}^{2}=0.091, \mathrm{~F}(1,245)\right.$ $=24.521, \mathrm{p}<.05)$. However, the unit of influece was less than $10 \%$.

Table 6 shows the results of the regression coefficient. A unit increase in service delivery increases the competitive advantage by 0.164 , while cost optimization increases the competitive advanatge by 0.182 and lastly, organization structure increases competitive advantage by 0.156 .

Table 6. Coefficients of process innovation constructs on competitive advantage

\begin{tabular}{|c|c|c|c|c|c|c|}
\hline & \multicolumn{2}{|c|}{ Hypothesis $\mathbf{H}_{\mathbf{0 1 a}}$} & \multicolumn{2}{|c|}{ Hypothesis $H_{01 \mathrm{~b}}$} & \multicolumn{2}{|c|}{ Hypothesis $\mathrm{H}_{01 \mathrm{c}}$} \\
\hline & (Constant) & $\begin{array}{l}\text { Service } \\
\text { Delivery }\end{array}$ & (Constant) & $\begin{array}{c}\text { Cost } \\
\text { Optimization }\end{array}$ & (Constant) & $\begin{array}{c}\text { Organization } \\
\text { Structure }\end{array}$ \\
\hline B & 2.94 & 0.137 & 3.035 & 0.112 & 3.043 & 0.109 \\
\hline Std. Error & 0.205 & 0.053 & 0.152 & 0.039 & 0.173 & 0.044 \\
\hline Beta & & 0.164 & & 0.182 & & 0.156 \\
\hline $\mathrm{T}$ & 14.339 & 2.597 & 20.011 & 2.895 & 17.561 & 2.479 \\
\hline Sig. & 0 & 0.01 & 0 & 0.004 & 0 & 0.014 \\
\hline
\end{tabular}

Source (Researcher, 2020)

On the service delivery, the regression model shows service deliver affects the competitive advantage of companies under the equation:

$Y=\beta_{0}+\beta_{i} x_{i}+\varepsilon$

$\mathrm{Y}=2.94+.164 \mathrm{X}+.053$ 
Thus rejects the null hypothesis: $\mathrm{H}_{01 a}:$ Service delivery has no significant influence on competitive advantage of telecommunications companies in Kenya.

On the cost optimization, the regression model shows service deliver affects the competitive advantage of companies under the equation:

$Y=\beta_{0}+\beta_{i} x_{i}+\varepsilon$

$\mathrm{Y}=3.035+.182 \mathrm{X}+.039$

Thus rejects the null hypothesis: $\mathrm{H}_{01 \mathrm{~b}}$ : Cost optimization has no significant influence on competitive advantage of telecommunications companies in Kenya.

On the organization structure, the regression model shows service deliver affects the competitive advantage of companies under the equation:

$Y=\beta_{0}+\beta_{i} x_{i}+\varepsilon$

$\mathrm{Y}=3.043+.156 \mathrm{X}+.044$

Thus rejects the null hypothesis: $\mathrm{H}_{01 c}$ : Organization structure has no significant influence on competitive advantage in the telecommunications industry of Kenya.

Table 7 shows the results of the regression coefficient of combined constructs to present the process innovation. The output shows process innovation statistically affect the competitive advantage $(\beta=.302 t=4.952, p<.05)$. The beta of 0.302 shows that one unit of increase in process innovation increases the competitive advantage of companies by 0.302 .

Table 7. Coefficients of process innovation on competitive advantage

\begin{tabular}{|c|c|c|c|c|c|c|}
\hline & \multirow{2}{*}{ Model } & \multicolumn{2}{|c|}{ Unstandardized Coefficients } & \multirow{2}{*}{$\begin{array}{c}\begin{array}{c}\text { Standardized } \\
\text { Coefficients }\end{array} \\
\text { Beta }\end{array}$} & \multirow{2}{*}{$\mathbf{t}$} & \multirow{2}{*}{ Sig. } \\
\hline & & B & Std. Error & & & \\
\hline \multirow[b]{2}{*}{1} & (Constant) & 2.166 & .302 & & 7.182 & .000 \\
\hline & $\begin{array}{l}\text { Process } \\
\text { innovation }\end{array}$ & .385 & .078 & .302 & 4.952 & .000 \\
\hline
\end{tabular}

Source (Researcher, 2020)

Thus from the regression model, process innovation affects the competitive advantage of companies and the regression model used was:

$Y=\beta_{0}+\beta_{i} x_{i}+\varepsilon$

$\mathrm{Y}=$ competitive advantage

$\beta_{0}=$ Constant

$\beta_{i}=$ process innovation

$\varepsilon=$ Error term

$\mathrm{Y}=2.166+.302 \mathrm{X}+.078$ 
Thus the study rejected the null hypothesis $\mathrm{H}_{0}$ : Process innovation has no significant effect on the competitive advantage of telecommunication companies in Kenya and adopted the alternative hypothesis $\mathrm{H}_{0}$ : Process innovation has a significant effect on the competitive advantage of telecommunication companies in Kenya.

\section{DISCUSSION OF STUDY FINDINGS}

The study sought to establish the relationship between process innovation and competitive advantage in telecommunications companies in Kenya. From the results of the hypothesis testing, there is a significant relationship between the process innovations and competitive advantage in the telecommunications companies in Kenya. The regression model showed for every unit process innovation by the telecommunication company, there was a correspoing 0.302 rise in competitive adantage, with a strong signifcant $\mathrm{p}$ value of $.000(\mathrm{p}<.050)$.

It is pointed out that firms spend as much as 30 percent of their time on upgrading the processes to make operations both internal and external by their customers much smoother than before (Bashir \& Verma, 2017). This has an effect on how synergies and partnerships can be created in the firm market by sharing the upgrade thus reducing the actual cost of development. In essence, the scholars reckon that all that matters for a customer is to go through any process as quickly as possible without so much queuing time. If the partnerships in a network can reduce the cost of development to a manageable level, then it becomes clear that each of them can be competitive in its field of specialisation.

The efforts in upgrading systems are not only vested in monitoring and evaluation but that a good firm should have it at all points in the line of production. This is also a view shared by Coccia and Wang (2015) who observe that there is always a network of organizations that enable firms to have specific processes that are not easily replicable and hence keeping the necessary competitive advantage at every state on the market. The partnering firms are then expected to generate a symbiotic relationship that can be held together by some positive profit margins. By so doing, firms have to maintain a strong research and development team that can benchmark processes that edge them ahead of the competition. This benchmarking takes the form of using new software as well as hardware that would quickly enhance the operations of the competing but collaborative firms on the market. Arrifian (2019) adds that firms that quickly adopt innovative processes will not only retain customers but also get new ones especially if the innovative process is creative enough to reduce costs thus creating a competitive edge.

The collaborative firms would in effect work to protect each other for the expensive software as well as equipment. This then requires that there is a special supplier of such software or hardware that would regulate the availability of these two to rival firms. There is also the observation that Costello (2019) made in which innovative processes can lead to new branch opening as well as new absorption of employees who could not be inculcated in the old process system. Another supporting study is from Möldner et al., (2020) who observed that the firms with new innovative processes require to have a good feedback system both internal and external in order to improve their processes. Kim et al., (2018) established that both the customers and the firm alike would best adopt processes that simplified operations and accelerated services. Mutua (2019) also found similar results in their study in which they concluded that process development led to high cost reduction. This would also encourage firms to set research and development teams that constantly monitor customer reactions to processes of the firm's services and more importantly have creative employees.

On the contrary, some scholars have disputed that innovative processes can be the major influencer of competitive advantage on the market. May and Schedelik (2019) in their study of comparative capitalism and innovativeness contend that process innovation in the face of poor services or products cannot be a key influence on competitive advantage. The scholars intimate that the synergies and collaborative partnerships could even become toxic if there are no immediate 
profits or gains by some of the partnering firms. This is to say that if a firm has multiple locations of service provision, then the processes might not all be the same and that in some locations, a process might be rejected thus giving no advantage to the firm or firms in collaboration. Tchamyou, Erreygers and Cassimon (2019) who earlier contended that unless the costs of the new process indicate a positive change in profits, the new process would remain a disadvantage to the firm also share this view. It clearly calls to question the cost of new software and hardware since these two could wipe away the competitive edge of the newly formed partnerships. The scholar adds that only careful design of the process can be of any advantage to the innovative firm. This would even lead to the dismantling of the created partnerships and costly dismantling of the installed software and hardware to enable the firms to regain some market advantage. According to Tageta, a workforce that would be costly to maintain on the new innovative process could be a hindrance to the firm thus discouraging venturing into that innovative process. This would mean an innovative process does not provide a competitive process for the firm.

\section{CONCLUSION}

The study results showed that process innovation has a significant effect on the competitive advantage of telecommunication companies in Kenya, hence concluded, Kenya telecommunication companies are creatively improving their ways and means of processing services as well as goods. Collaborations and synergy creation can only work if there is some form of profitability increasing the competitive advantage of the firms in question. However, process innovation as an influence of competitive advantage means that the telecommunication companies keep such processes as top secrets that cannot be easily copied by their rivals except those they have full collaborations or partnerships on the existing market. It also suffices to observe that the influence of process innovativeness on competitive advantage leads to many telecommunication companies remaining on the market since it is somehow manageable to maintain the simple processes that make them run on a daily basis. This is only possible if the cost of the hardware and new GSM networks are within acceptable costs as well as redefining employees roles in the organisation. The positive results of process innovation also lead to the conclusion that it must be a contributing factor in the telecommunication companies' profit-making. Customers of the industry are also most likely to be enjoying the processes, which help them get services. It is therefore fair to conclude that process innovation is a strong factor in influencing the competitive advantage of telecommunication companies in Kenya which require constant research and development for keeping in touch with the rest of the world technologically.

\section{Recommendations and Implications on Policy, Limitations, Theory and Practice}

The telecommunication companies could use the findings to upgrade their processes by efficiently designing those that provide optimum returns without detrimental effects on the environment. The government of Kenya could also use the findings of this study to help design policy on what hardware or software technologies to be used. New processes of paying for services in private and public sector should be encoraged especially during the Covid-19 pandemic.Farmers can use new proceses to get better yields and ready markets for their farm produce. This in turn will reduce cost of warehousing for farm produce. This means that the Kenyan government through Communications Authority of Kenya could set up guidelines on the adoption of specific process innovations in order to avoid innovations that could prove controversial in the market such as money lending applications that are niot regulated by the regulator. The study was limited to telecommunication industry and a deep dive in the health sector would provide new processes to curb the inefficiecies in the contact tracing, quarantine management and home follow ups for Covid 19 patients. 


\section{REFERENCES}

Aghion, P., Bergeaud, A., Boppart, T., Klenow, P. J., \& Li, H. (2019). Missing growth from creative destruction. The American Economic Review, 109(8), 2795-2822. doi:10.1257/aer.20171745

Anning-Dorson, T. (2018). Innovation and competitive advantage creation. International Marketing Review, 19(6), 215-224.

Arifiani, L. (2019). The Effect of Disruption Technology, Opportunities and Challenges of Telecommunication Industry 4.0 in Indonesia. Decision Making, 5, 7.

Atalay, M., Anafarta, N., \& Sarvan, F. (2013). The Relationship between Innovation and Firm Performance: An Empirical Evidence from Turkish Automotive Supplier Industry. SBSPRO Procedia - Social and Behavioral Sciences, 75, 226-235.

Bashir, M., \& Verma, R. (2017). Why business model innovation is the new competitive advantage. IUP Journal of Business Strategy, 14(1), 7.

Bloch, H., \& Metcalfe, S. (2018). Innovation, creative destruction, and price theory. Industrial and Corporate Change, 27(1), 1-13. doi:10.1093/icc/dtx020

Bryman, A., \& Bell, E. (2015). Business research methods. Oxford University Press.

CAK. (2018). The Annual Report for the year 2018. Retrieved on 20.02.2019 at www.ca.go.ke/downloads/ reports.pdf

Carver, A. (2018). Open and secret regulations and their implication for foreign investment. In Management Issues in China (Vol. 2, pp. 11-29). Routledge.

Christensen, C. M., McDonald, R., Altman, E. J., \& Palmer, J. E. (2018). Disruptive innovation: An intellectual history and directions for future research. Journal of Management Studies, 55(7), 1043-1078. doi:10.1111/ joms. 12349

Coccia, M., \& Wang, L. (2015). Evolutionary convergence of the patterns of international research collaborations across scientific fields. Academic Press.

Corsi, S., \& Di Minin, A. (2014). Disruptive innovation in reverse: Adding a geographical dimension to disruptive innovation theory. Creativity and Innovation Management, 23(1), 76-90. doi:10.1111/caim.12043

Costello, G. J. (2019). Proposing an innovation-based view of the firm. Irish Journal of Management, 37(1), 65-79. doi:10.2478/ijm-2018-0006

Creswell, J. W., \& Poth, C. N. (2018). Qualitative inquiry and research design: choosing among five approaches. SAGE Publications.

David, M. (2017). Moving beyond the heuristic of creative destruction: Targeting innovation with policy mixes for energy transitions. Energy Research \& Social Science, 33, 138-146. doi:10.1016/j.erss.2017.09.023

David, O. O. (2019). Nexus between telecommunication infrastructures, economic growth and development in Africa: Panel vector autoregression (P-VAR) analysis. Telecommunications Policy, 43(8), 101-116. doi:10.1016/j. telpol.2019.03.005

Desta, T. (2018). ICT Innovations, entrepreneurship and hubs in East Africa: The case of Ethiopia. African Journal of Science, Technology, Innovation and Development, 10(6), 655-664. doi:10.1080/20421338.2018.1473064

Fonseca, T. (2014). Combining product and process innovation: Is organizational innovation the crucial complement. Economics, 24(4), 557-579.

Ghezzi, A., Cortimiglia, M. N., \& Frank, A. G. (2015). Strategy and business model design in dynamic telecommunications industries: A study on Italian mobile network operators. Change Technological Forecasting and Social Change, 90(PA), 346-354.

Gituma, A., \& Gachunga, D. H. (2016). Influence of Organizational Restructuring on performance of telecommunication industry in Kenya, A Case of Airtel Kenya Ltd. The Strategic Journal of Business \&Change Management, 3, 379-40. 
Gobble, M. M. (2016). Defining disruptive innovation. Research Technology Management, 59(4), 66-71. doi: $10.1080 / 08956308.2016 .1185347$

Guimaraes, T., Paranjape, K., Cornick, M., \& Armstrong, C. P. (2018). Empirically testing factors increasing manufacturing product innovation success. International Journal of Innovation and Technology Management, 15(02), 1850019. doi:10.1142/S0219877018500190

Haneda, S., \& Ito, K. (2018). Organizational and human resource management and innovation: Which management practices are linked to product and/or process innovation? Research Policy, 47(1), 194-208. doi:10.1016/j. respol.2017.10.008

Hassan, M. U., Shaukat, S., Nawaz, M. S., \& Naz, S. (2013). Effects of innovation types on firm performance: An empirical study on Pakistan's manufacturing sector. Pakistan Journal of Commerce and Social Sciences, 7(2), 243.

Hopp, C., Antons, D., Kaminski, J., \& Oliver-Salge, T. (2018). Disruptive innovation: Conceptual foundations, empirical evidence, and research opportunities in the digital age. Journal of Product Innovation Management, 35(3), 446-457. doi:10.1111/jpim.12448

Howes, O. (2015). Linking Core Competence, Innovation and Firm Performance. Işletme Araştırmaları Dergisi, 7(1), 90-102.

Igami, M. (2017). Estimating the innovator's dilemma: Structural analysis of creative destruction in the hard disk drive industry, 1981-1998. Journal of Political Economy, 125(3), 798-847. doi:10.1086/691524

Jayateertha, G. M., Garcia, N. M., \& Talukder, A. K. (2014). Convergence through all-IP networks. Academic Press.

Kim, K., Baek, C., \& Lee, J. D. (2018). Creative destruction of the sharing economy in action: The case of Uber. Transportation Research Part A, Policy and Practice, 110, 118-127. doi:10.1016/j.tra.2018.01.014

Kingiri, A. N., \& Fu, X. (2020). Understanding the diffusion and adoption of digital finance innovation in emerging economies: M-Pesa money mobile transfer service in Kenya. Innovation and Development, 10(1), 67-87. doi:10.1080/2157930X.2019.1570695

Landoni, M. (2017). Innovation policy in progress. Institutional intermediation in public procurement of innovation: Satellite telecommunications in Italy. $R$ \& D Management, 47(4), 583-594. doi:10.1111/radm.12246

Lepoutre, J., \& Oguntoye, A. (2018). The (non-) emergence of mobile money systems in Sub-Saharan Africa: A comparative multilevel perspective of Kenya and Nigeria. Technological Forecasting and Social Change, 131, 262-275. doi:10.1016/j.techfore.2017.11.010

Li, M., Porter, A. L., \& Suominen, A. (2018). Insights into relationships between disruptive technology/innovation and emerging technology: A bibliometric perspective. Technological Forecasting and Social Change, 129, 285-296. doi:10.1016/j.techfore.2017.09.032

May, C., \& Schedelik, M. (2019). Comparative capitalism and innovation policy: Complementarities and comparative institutional advantage. Journal of Economic Policy Reform, 1-16. doi:10.1080/17487870.2019. 1637589

McDowall, W. (2018). Disruptive innovation and energy transitions: Is Christensen's theory helpful? Energy Research \& Social Science, 37, 243-246. doi:10.1016/j.erss.2017.10.049

Möldner, A. K., Garza-Reyes, J. A., \& Kumar, V. (2020). Exploring lean manufacturing practices' influence on process innovation performance. Journal of Business Research, 106, 233-249. doi:10.1016/j.jbusres.2018.09.002

Moyano-Fuentes, J., Maqueira-Marín, J. M., \& Bruque-Cámara, S. (2018). Process innovation and environmental sustainability engagement: An application on technological firms. Journal of Cleaner Production, 171, 844-856. doi:10.1016/j.jclepro.2017.10.067

Mutua, C. (2019). Article critique competitive advantage: A critique of 3 journal articles. International Journal of Advanced Research in Management and Social Sciences, 8(5), 23-32.

Nawal, A., \& Cherif, B. M. (2019). Telecommunications sector transformations, innovations and the market structure: The case of Algeria. International Journal of Technology Management \& Sustainable Development, 18(3), 279-299. doi:10.1386/tmsd_00010_1 
Njoh, A. J. (2018). The relationship between modern information and communications technologies (ICTs) and development in Africa. Utilities Policy, 50, 83-90. doi:10.1016/j.jup.2017.10.005

OECD. (2015). OECD communications outlook 2015. Paris, France: OECD. Retrieved on 12.03.2020 from https://site.ebrary.com/id/10245619

Ole Kulet, J. L., Wanyoike, D. M., \& Koima, J. K. (2019). Effects of best product strategic positioning on organizational performance in telecommunication industry. Kenya. The Strategic Journal of Business \& Change Management, 6(1), 387-400.

Osano, H. M., \& Koine, P. W. (2016). Role of foreign direct investment on technology transfer and economic growth in Kenya: A case of the energy sector. Journal of Innovation and Entrepreneurship, 5(1), 31. doi:10.1186/ s13731-016-0059-3

Reichstein, T. (2016). Investigating the sources of process innovation among UK manufacturing firms. Elsevier.

Reinhardt, R., \& Gurtner, S. (2018). The overlooked role of embeddedness in disruptive innovation theory. Technological Forecasting and Social Change, 132, 268-283. doi:10.1016/j.techfore.2018.02.011

Sandström, C., Berglund, H., \& Magnusson, M. (2014). Symmetric assumptions in the theory of disruptive innovation: Theoretical and managerial implications. Creativity and Innovation Management, 23(4), 472-483. doi:10.1111/caim.12092

Sipos, G. L., \& Ionescu, A. (2015). The influence of different innovation types upon the innovative performanceevidence from European Countries. Management \& Marketing Journal, 13(1).

Song, A. K. (2019). The Digital Entrepreneurial Ecosystem-A critique and reconfiguration. Small Business Economics, 53(3), 569-590. doi:10.1007/s11187-019-00232-y

Tchamyou, V. S., Erreygers, G., \& Cassimon, D. (2019). Inequality, ICT and financial access in Africa. Technological Forecasting and Social Change, 139, 169-184. doi:10.1016/j.techfore.2018.11.004

Tesfaye, H. G., \& Nguyen, T. H. N. (2012). Incumbent firms and Response to Disruptive Innovation through Value Network Management Lessons from Eastman Kodak's failure in the digital era. Unpublished Master of Science. Linköping University.

Vecchiato, R. (2017). Disruptive innovation, managerial cognition, and technology competition outcomes. Technological Forecasting and Social Change, 116, 116-128. doi:10.1016/j.techfore.2016.10.068

Vogelsang, I. (2017). The role of competition and regulation in stimulating innovation-Telecommunications. Telecommunications Policy, 41(9), 802-812. doi:10.1016/j.telpol.2016.11.009

Wasono, L. W., \& Furinto, A. (2018). The effect of digital leadership and innovation management for incumbent telecommunication company in the digital disruptive era. IACSIT International Journal of Engineering and Technology, 7(2.29), 125-130. doi:10.14419/ijet.v7i2.29.13142

Peter Mugo is a Doctorate Student of Strategic Management at United States International University- Africa, School of Business. He holds a Masters in Business Administration specializing in Strategic Management from USIU-A. He has an interest in innovation in e-commerce and financial inclusion. He is a member of the Doctoral Association of East Africa.

Juliana M. Namada is an Assistant Professor of Strategic Management at United States International UniversityAfrica, School of Business. She holds a PhD and Masters in Business Administration specializing in Strategic Management from the University of Nairobi She teaches and supervises students in Business Administration at undergraduate, Masters and Doctoral levels in the university. She has published in refereed journals both locally and internationally. She has published four book chapters. Her research interests are in strategic management with a bias in strategic planning. Dr. Juliana is a member of the Academy of Management and Africa Academy of Management. In terms of service to the profession, She is an editorial member of two peer reviewed journals and reviews for several refereed journals. She is a past Global Representative for Africa in Academy of Management -Strategic Management Division. 